\title{
Aesthetic Sense of the Vietnamese through Three Renovations of
}

\section{the Women's Ao dai in the $20^{\text {th }}$ Century}

\author{
Duong Thi Kim Duc ${ }^{1,2}$ \& Mingxin Bao ${ }^{1}$ \\ ${ }^{1}$ Fashion Art Design Institute, Donghua University, Shanghai, China \\ ${ }^{2}$ School of Textile - Leather and Fashion, Hanoi University of Science and Technology, Hanoi, Viet Nam \\ Correspondence: Duong Thi Kim Duc, Fashion Art Design Institute, Donghua University, 1882 Yan'an Road \\ West, Shanghai 200051, China. Tel: 86-150-2178-8386. Email: eviet_fashion@yahoo.com
}

Received: March 28, 2012

Accepted: April 28, 2012 Published: July 1, 2012

doi:10.5539/ach.v4n2p99

URL: http://dx.doi.org/10.5539/ach.v4n2p99

\begin{abstract}
Ao dai is a typical long dress of Viet Nam used to be worn by both men and women of the Viet and other ethnic peoples. In her shaping and development history, Viet Nam became a place that converged various cultural flows such as the Vietnamese indigenous culture and that of the Chinese, Champa and Indian etc. To the end of the $19^{\text {th }}$ century, especially the $20^{\text {th }}$, Viet Nam continued to be influenced by the French culture and the American ways of living. The acceptance of cultures from various nationalities and communities from the North to South, East to West made it possible for the Vietnamese fashion designers to harmonize all into an Ao dai for the Vietnamese women. This article will synthesize and analyze three renovation movements of Ao dai in the $20^{\text {th }}$ century. It also discusses about these processes and introduces typical innovators whose contribution has created the Ao dai as it is today, a traditional dress that represents history of the Vietnamese culture, aesthetic sense, art and vitality.
\end{abstract}

Keywords: Ao dai, renovation trends, designers, Ao dai renovation

Movements to renovate the Vietnamese Ao dai originated since the 1930 s of the $20^{\text {th }}$ century. Thirty years later, there appeared a new renovation movement with typical Ao dai renovators. (The first trend: During the thirties. The second, the sixties and seventies, and the third: The nineties). These renovations have all grounded on the tradition and acquired the then aesthetic senses combined with the American European designing techniques. The perception and approach to create styles of the then renovators remain useful experience for the designers today, who want to combine the traditional styles with the modern ones.

\section{The First Renovation Movement: The Thirties of the $20^{\text {th }}$ Century}

\subsection{Situation in Vietnam before the First Movement to Renovate Ao dai}

Viet Nam in the late nineteen and early twentieth century was under the feudal Nguyen Dynasty. The main "traditional appearance of the Vietnamese costume, whose background was shaped since the time of the King Hung, and went through nearly twenty centuries of development and exchange, has become nearly perfect" (Ngo Duc Thinh, 1994). There are not only diversified styles and modes of the Viet people, but also the especially excellent ones of the 53 brotherly ethnic minorities in the Vietnamese territory.

\subsection{Renovation Context}

In the early 20th century, Vietnam, a semi-feudal society was under the French colonialism. This was the first time the Vietnamese traditional culture contacted the modern West through the French culture in a compulsory manner. Western-style cities were gradually built and new careers appeared. In addition, the division of spirit took place more and more distinctively. More people went to the West to study that resulted in the import of various new thoughts, knowledge and cultures into the spirit life of the Vietnamese society. More new forms of art and culture such as reformed theatre, play, novel, press... appeared. The Vietnamese people had more chances to contact with the civilization, art and even the French Paris fashion (Nguyen Luong Tieu Bach,2005). In such context, Ao dai of the Vietnamese women has been renovated following a trend to be urbanized by 
integrating new Western elements. (Figure1). Meanwhile in the rural area, it basically remained unchanged in comparison with that in the past period.

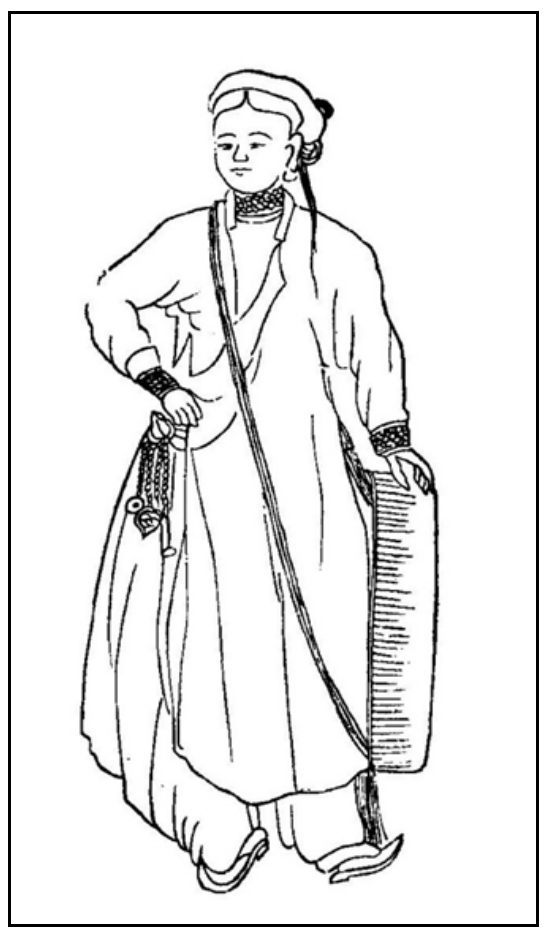

Figure 1a. Costume: urban women's Ao dai (Wooden painting by Henri Oger. Technique du peuple Annamite. 1908-1909)

Figure $1 \mathrm{~b} \& \mathrm{c}$. Hanoian women in Ao dai in the French Indochinese post card at the beginning of 20th century

\subsection{Typical Designers}

In 1934, on the Dep (beauty) subject of Phong Hoa newspaper, artist Nguyen Cat Tuong introduced a collection called "Hoa Hong Gio Ty" (roses in the midnight) that included modes named "Le Mur", meaning 'cat tuong' in Vietnamese but 'auspicious' in English. Although it created a great resound, 'Lemur' faced astrong opposition from the conservative Confucian scholars. Later, as artist Le Pho adjusted some details (Figure2c), "Ao dai Lemur" become convincing to women from North to South.

\section{Artist Nguyen Cat Tuong}

Brief introduction: Artist Nguyen Cat Tuong (1911-1946) graduated in 1934 from the Indochina College of Fine Arts. He was, together with artist Nguyen Gia Tri, in charge of the Art subject for Phong Hoa and Ngay Nay newspapers. He actively participated in social reform activities laid by Phong Hoa newspaper and the "Tu Luc Van Doan” (Self-help Literature Association).

Regarding 'costume of women', his outlook was that "although clothes are used to cover the body, it could be a mirror to reflect the level of knowledge of a nation" (Cat Tuong, 1934). Concerning the renovation, he articulated: “... the dress of you girls; first of all, it must be suitable for the climate in our region, for different seasons, for your work and the measurement of your body. Then it has to be neat, simple, sinewy, artistic and well-mannered. But no matter how it looks like; it must bear our own nation's characters" (Cat Tuong, 1934).

He specified the modification of Ao dai as follows: "As I said, it's the collar that is redundant, and the sleeves inconvenient... We were created with different forms... Therefore, the dress has to be added or cut in accordance with each person" (Cat Tuong, 1934). He also stressed the advantages of the Ao dai he designed such as "has its own character; is hygienic and artistic; can increase the charming of the "fair sex". To achieve such effects, he narrowed the waist as he explained "I made the belly a little tighter because I want to clearly 
differentiate the belly and the bosom" (Cat Tuong, 1934). He asserted that the West's conception of the women's beauty is coincident with local traditional conception "that day lung ong" (wasp-waisted) of the Vietnamese girls.
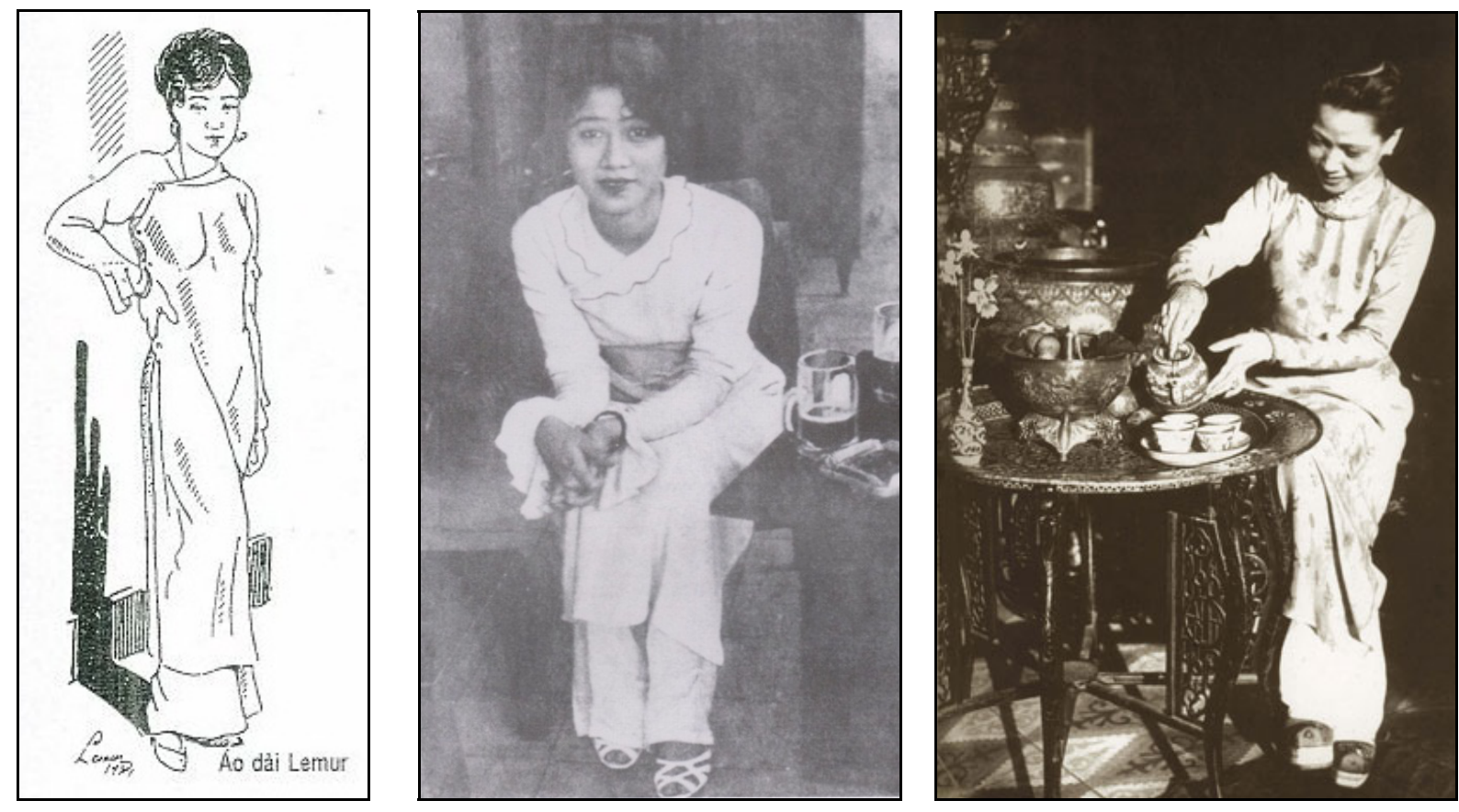

Figure $2(a, b, c)$

Figure 2a. A sketch of Ao dai in Phong Hoa newspaper designed by Lemur

Figure 2b. Miss Nguyen Thi Hau in Ao dai Lemur, 1930s

Figure 2c: Ao dai of Le Pho

Regarding the front and back tails of the Ao dai, he believed that it was better to make them tidier. Regarding the trousers worn inside the tails, he had considerable improvements such as "from the waist to the knee, it should be narrower to fit the body (thighs). That is to make the natural beauty of girls exposed. And the part from the knees to the cuffs, the two trouser legs should be flaring to make the girls look more gently" (Cat Tuong, 1934).

He also cared about the underwear inside Ao dai because "wearing modern Ao dai without proper underwear could be unaesthetic". He further opened a workshop to make high heel clogs designed by him, and organized "Ao dai fashion shows" from North to South in trade fairs with models selected from students and intellectuals to perform the costumes designed by himself (Figure 2a, b).

Comment: Today, someone may ask whether artist Cat Tuong was the first person who renovated Ao dai or not (Note 1). However, basing on photos and articles published on Phong Hoa newspapers during those days, one could relatively admit his conception and means as well as his contribution to the renovation of Ao dai for the Vietnamese women. He might copy the West on how to "express" graphic elements in costume design but more importantly, he has engendered a new form of Ao dai, fashionable but still contains specific characters of the Vietnamese women. On the basis of this aesthetic conception, future designers continued to follow the way he had mapped out.

\section{The Second Renovation Movement: The Sixties and Seventies of the $20^{\text {th }}$ Century}

\subsection{Renovation Context}

To the end of the $19^{\text {th }}$ century, Saigon had become "the pearl of the Far East" - a centre of culture and economy of a French colony. After the French, the American had changed Sai Gon into the capital of the Sai Gon Administration for 20 years (1955-1975). The American ways of living (hurried, self-satisfied and individualism) 
gradually replaced the French culture. This affected Sai Gon in many aspects... Sai Gon had made the most of her internal strength to, on the one hand, assimilate the positive elements (of the American culture) and on the other hand, to reject the exotic ones that were against the traditional culture of the Vietnamese nation ( Nhieu tac gia, 2005).

\subsection{Typicaldesigners}

Along with the American culture and ways of living such as jeans, flared trousers, 'hippy' and 'miniskirt', the $2^{\text {nd }}$ renovation movement took place in various manners. On 6 December 1958, in the Household Arts Exhibition at $\mathrm{Nu}$ Vuong Hoa Binh Orphanage, Tran le Xuan, the First Lady appeared in Ao dai with boat-shaped collar (half-moon shape) and short sleeves. Her arms were in white gloves and her hairs done high up in a chignon. Then this style was imitated by some ladies in the Jointly Women Association. They cut their Ao dai with open neck collar, or rounded, squared or heart-shaped style.

\section{Tran Le Xuan}

Brief introduction: Tran Le Xuan was born in 1924 in Hanoi from a royal family of the Nguyen dynasty. She acquired the French education. In 1943, she married Mr. Ngo Dinh Nhu who was a younger brother and advisor of the then President of the Vietnam Republic Ngo Dinh Diem. That is why she was titled 'Madam Advisor' or 'The First Lady' of the Vietnam Republic (1955-1963) due to her powerful position.

Madam Tran Le Xuan was also known as the prophet of the modern collar Ao dai called "Ao dai Tran Le Xuan"( BBCVietnamese, 2011). She used to appear in public in V-shaped collar and short sleeved Ao dai. Her arms were in white gloves, her hairs done high up in a chignon and her neck gently wearing a simple necklace (Figure 3a, b).
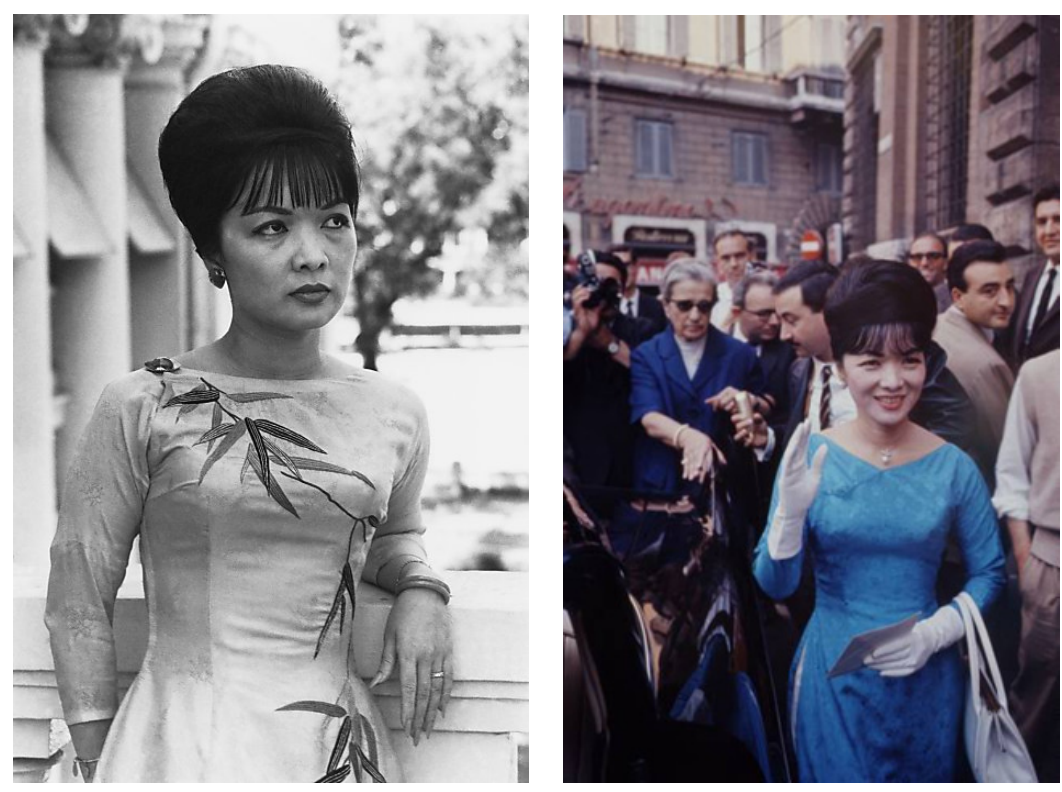

Figure $3(\mathrm{a}, \mathrm{b}, \mathrm{c})$

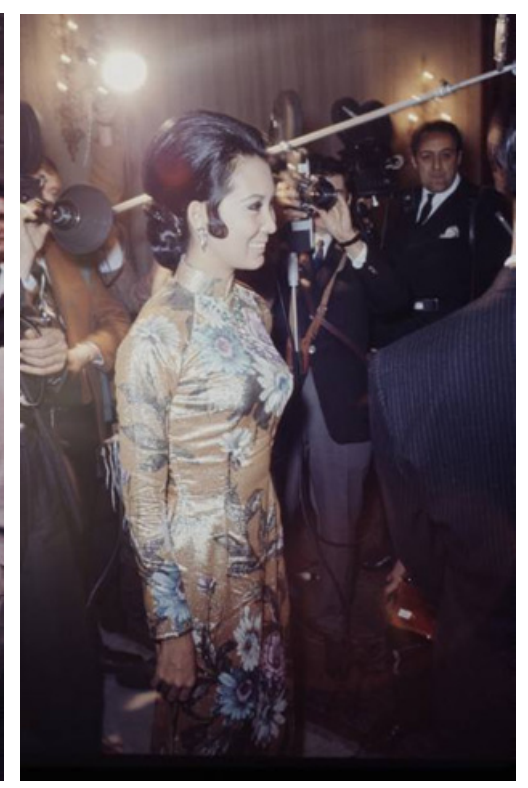

Figure 3a. The First Lady Tran Le Xuan at Gia Long Palace (Photo: Manh Hai- Associated Press. 1963)

Figure 3b: Tran Le Xuan in Paris. 1963 (photo: LIFE)

Figure 3c. Ao dai Raglan (Ms. Dang Tuyet Mai, Paris. 1969. Photo by Loomis Dean)

Comment: Many articles and novels were written about the idea of Lady Tran Le Xuan to renovate the Ao dai. However, in her final years in Paris, she referred to that renovated Ao dai in an interview that "It's very hot in Saigon. So when I wear Ao dai with open collar, the President was not satisfied" (CAND, 2009). This indicated the conception of the traditional Vietnamese women in that period. Although they accepted pragmatism to 
renovate the collar to adapt to the climate of the South of Vietnam, the convenience of costume sometimes is not the symbol of the traditional aesthetic conception of the Vietnamese women.

\subsection{Other Renovations}

Brief introduction: In the early 1960s, a tailor in Dakao named Dung launched a new model: the "Ao dai Raglan" (Figure3c) wearing with slanted trousers. The way to sew the sleeves and the body at the armpit and shoulder helped erasing the crumpled marks beside the armpits and shoulders and improving aestheticism of the upper part of Ao dai. The slanted trousers made of soft cloth holding more closely the bottom and the thighs but flaring in the lower part made the shoe appear and disappear alternately under the silk waves when the girl was walking.

In 1968, young girls liked to wear a new Ao dai style made of colorful cloth, with the front and back tails as short to the knees only. They called it "Ao dai hippy" (Note 2). However, this was not preferred by the majority. Many of them only accepted to wear Ao dai made of cloth printed with flowers during special occasions such as wedding or dancing party.

In the early 1970s, to adapt to miniskirt of girls and flared trousers of boys according to the hippy style, "Ao dai mini" appeared and immediately become up-to-date mode. The tails of Ao dai was narrower and short to the knees sometimes. The body part was bigger and the waist was not taken in but still attached to the curves of the body. The collar was lowered by three centimeters. The shoulders were cut according to raglan style so that it could hold close to the bosom and arms. Meanwhile, the trousers were very long and their fringes made as wide as 60 centimeters.

Comment: In the late 1960s and early 1970s, Ao dai of the Vietnamese women had directly contacted the then various world fashion styles. Such experiments with various textures, proportions and ornamentation had laid foundation for further improvements to perfect the Ao dai as it is today.

\section{The Third Renovation Movement: The 1990s of the $20^{\text {th }}$ Century}

\subsection{Renovation Context}

During the 1980s, the world fashion with the advertising branch and fashion models vigorously developed and truly became a highly cultured industry. The emergence of the Asian fashion designers who have become the famous ones among the world's, and the journey to the East, all together have changed the thought of fashion creation in the world (Kim Duc, 1997). In addition to that, the renovation and integration of the economy of Vietnam started from 1986 have produced strong impacts on the Vietnamese, both people and culture. In the early 1990s, the Vietnamese fashion witnessed pleasing changes. In designing Ao dai, there emerged a model maker Ngan An in Hanoi. In the field of fashion show, there were Ao dai collections inspired by the idea of "national costume" designed by artist Minh Hanh and artist Sy Hoang. Those eventually led to the third Ao dairenovation movement.

\subsection{Typical Designers}

Ngan An

Brief introduction: The Hanoian designer Ngan An, though not being a designer with extraordinary improvements during the late of 1980s and early 1990s, was soon to achieve certain successes with Ao dai models bearing Hanoi style.

Before pursuing Ao dai and costumes of other ethnic minorities in Vietnam, she had 20 years acting as a well-known player in Hanoi. In 1986, she left the stage and was officially in charge of fashion design in Hanoi Fine Art Company. In 1993, Ngan An won gold medal for Ao dai in the international trade fair of industrial products held in Hanoi. In 1995, she was selected by the press to award the title of "Ban Tay Vang" (golden hand) of Vietnam. In addition to organizing fashion shows of Ao dai in South Korea, Singapore, Thailand and the Francophone Summit, she also cooperated with a famous Japanese fashion designer, Kansai, to organize an imposing fashion show called "Hello Vietnam" in Hanoi.

Her Ao dai made of green bamboo brocade worn by Ms. Truong Quynh Mai in the Miss International Contest in 1995 won the prize "The Most Beautiful National Costume" helped honoring the Vietnamese Ao dai in the international arena. (Figure $4 \mathrm{a}, \mathrm{b}$ ). 

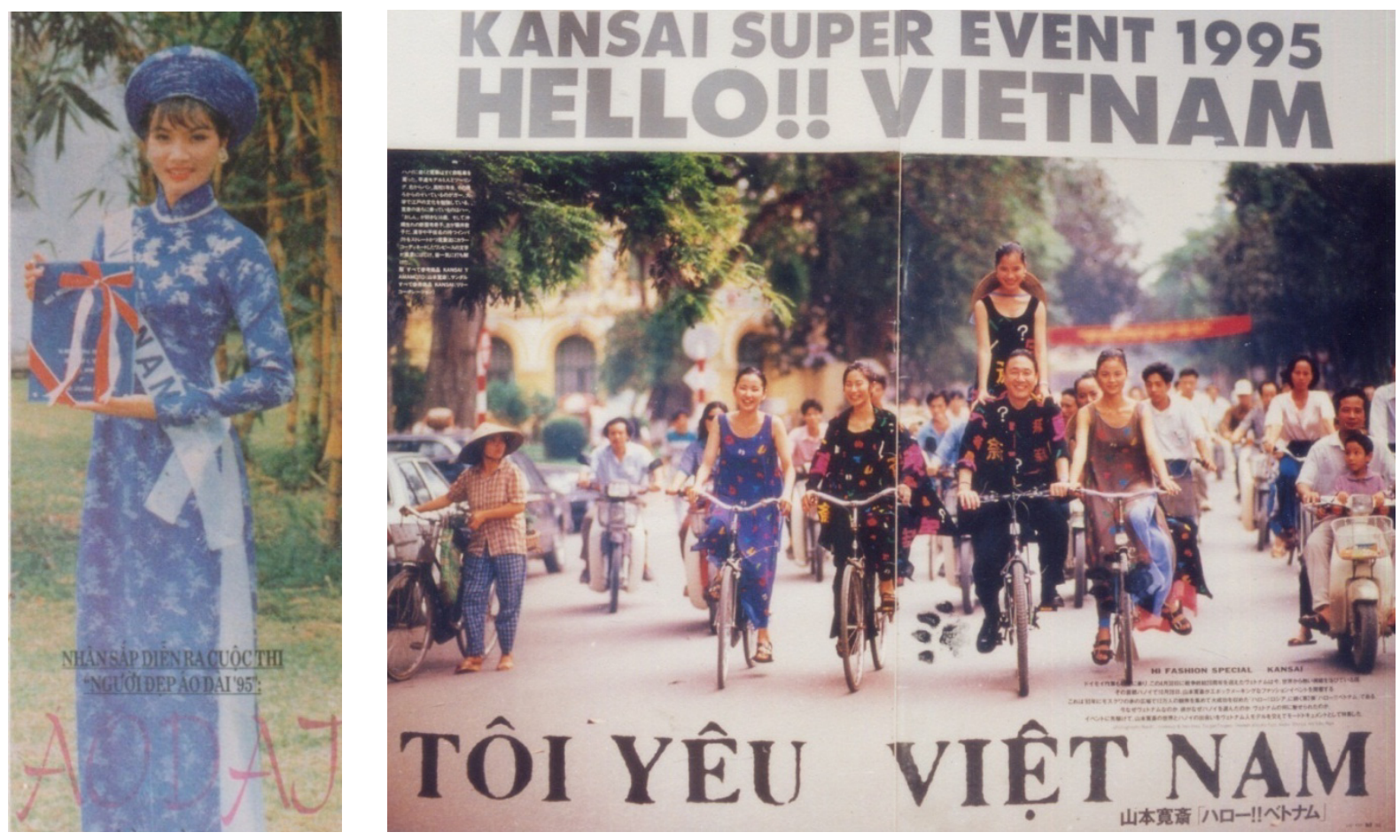

Figure $4(a, b)$

Figure 4a. Miss Truong Quynh Mai, "Most Beautiful National Costume", 1995

Figure 4b. Ao dai designed by Kansai in Hanoi, 1995

In the following years, her name has become popular in many social activities in Vietnam. She is also a famous memberof almost beauty and fashion contests. Her Ao dai or wedding dress models have been very much loved by ladies, artists, businesswomen, diplomats and foreign visitors.

Comment: In addition soul and sense of an artist, and the passion on designing national costumes, especially Ao dai of the Vietnamese women, Ngan An's Ao dai models have not only managed to succeed the traditions of Hanoi women, ingeniousness and responsibility, but also automatically become a natural mixture of the Vietnamese traditional culture and the beauty of Hanoi women, fervent, tender, courteous and smart.

Minh Hanh

Brief Introduction: Minh Hanh was born in Pleiku from a family native of Hue city. After graduating from Gia Dinh Fine Art School, she worked as a newspaper artist for years, and then moved to work for a fashion journal. In 1992, she became the manager of Fashion Center named Legafashion, the first one in Vietnam. In 1994, she came to work in the Institute of Vietnam Fashion Models (Fadin). In June 2006, she was the first Vietnamese fashion designer being awarded with the title of "Knight" in art and literature by the French Government(Hoai Nam, 2006).

Designer Minh Hanh spent much of her time to honor the Vietnamese Ao dai which, according to her, is "a language that needs no translator" (Toan Nguyen, 2006). Responding to a question "Why do you focus only Ao dai?" she said "The combination of traditional and modern is the right and shortest road for any Vietnamese fashion designer. Every designer's style must be stamped with the origin. Ao dai to me is a precious thing spared for the Vietnamese women. In this career, designing Ao dai is the most difficult task. Any young designer who desires to grow up has to overcome this first challenge" (Toan Nguyen, 2006).

Starting with an Ao dai made of "Tho Cam" (a type of brocade manually weaved by ethnic women of Vietnam) that was prized in a contest in Japan in 1977 (Figure 5a), Minh Hanh initiated a modernization of materials for Ao dai of the Vietnamese women. This attracted attention of fashion makers to the beauty of the traditional costumes of different ethnic peoples in Vietnam. Using fashion shows as a key means, she deserved credit for extending and popularizing the Ao dai culture at home and abroad. 
At home, Minh Hanh has initiated and organized Ao dai festival at Festival Hue in 2000, 2002, 2004, 2006, 2008, and 2010. Through these festivals, Ao dai design and performance have been expanded and helped to shape various designing styles for Ao dai of the Vietnamese women.

She was also a designer who successfully introduced Ao dai fashion collection abroad. In September 1997, owing to the prize she got in a contest in Japan in 1977, she was invited as the first foreign designer to introduce 100 models of her collection of Ao dai Vietnam named "Tradition and Future" in Kiyomizu temple - Dera. After that event, she successively introduced her collection of Ao dai in Germany (September, 1999) and the collection "Dragon and Butterfly" in Italy (June, 2006), participated in the week for international fashion show in Italy (January, 2009). (Figure 5b), then, "The Vietnamese Month in Lorient", France (May, 2011) and next, the Water Festival in China and finally, the Ao dai performance in England (December, 2011).(Figure 5c).
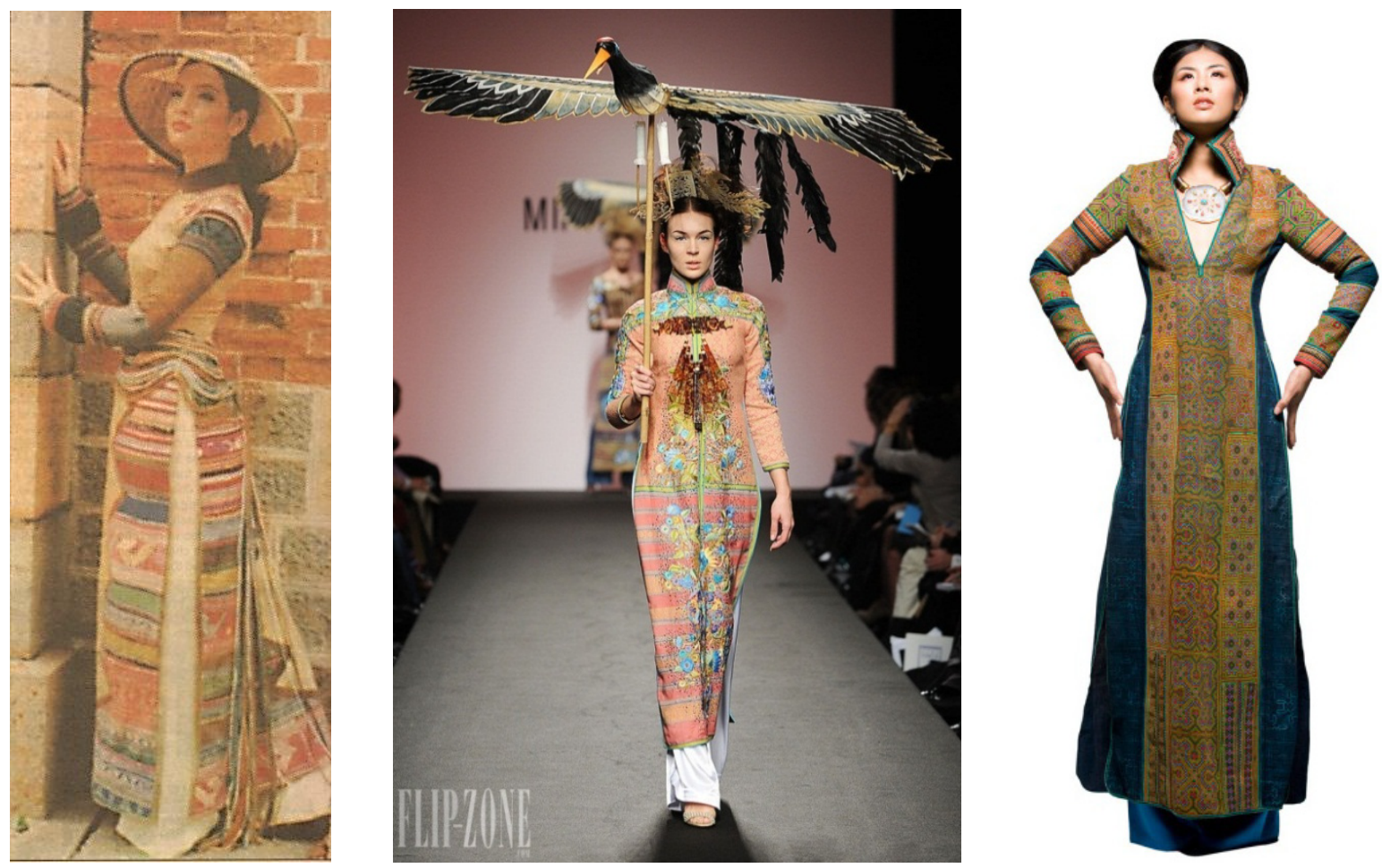

Figure $5(\mathrm{a}, \mathrm{b}, \mathrm{c})$

Figure 5a. Ao dai of Minh Hanh awarded with "New Designer Award" in the contest of Makuhari Grand Prix in Japan, 1997

Figure 5b. Ao dai collection of Minh Hanh in Rome, 2009 ( Photo: Luca Sorrentino )

Figure 5c. Ao dai collection of Minh Hanh in London, 2011 (Photo: Hai Dong)

Comment: It can be said that Minh Hanh's most success is in Ao dai performance. She is also a pioneer in combining material and vignette from the ethnic peoples' traditional costumes (mainly brocade of ethnic peoples from the North of Vietnam) in Ao dai to reflect the unified beauty in the diversified cultures of Vietnam. She deserves to be a pioneer who has a great influence on young fashion designers in designing modern Vietnamese costumes in general and renovating Ao dai in particular.

Sy Hoang

Brief introduction: Sy Hoang was born in Saigon. He started his career in 1989. From the successes in designing single Ao dai for contestants of "Miss Ao dai in Ho Chi Minh City" (first time in 1989, second time in 1995 and won the prize titled "The Best Ao dai Design" performed by the second-best Miss Vo Ngoc Hoang Hoa), his first Ao dai collection titled "National Patterns" has opened Sy Hoang's philosophy in designing "bringing 
painting art into traditional costumes and searching for creative ideas from the treasure of national cultures"( $\mathrm{Si}$ Hoang) (Figure6a). Every year after that, Sy Hoang successively gave birth his Ao dai collections such as: The "National Pattern" (1995), "Kaleidoscope" (1996), "The Night of Flower Garlands and Colored Lanterns" (1997), the wedding Ao dai called "Imperial Hue Palace" and "Masks of Tuong" (Tuong: classical drama of Vietnam) (1998) (Figure 6b), the "Ancient Incense" (2005) and "Dong Son Legend" and "Ao dai of Vietnam" (2008).

With his Ao dai designs, Si Hoang has contributed to build and spread the beauty of the "Vietnamese Ao dai culture" at home and abroad. His Ao dai collections have been performed many times in Festival Hue, the "Charming Vietnam" programmer and in other important festivals of the country. His collections were also performed in Belgium (2001), Germany (2003), Sweden (2004), France (2005) and San Jose of America (2006).

In 2005, Sy Hoang launched a movement to create drawings and Ao dai for children. He performed his Ao dai for children collection called "This Earth Is Ours" (2005) and "I'm here with you, Life" (2005). He also organized children's Ao dai drawing contest called "Little Designing Talents" (2008) and "the $12^{\text {th }}$ Ho Chi Minh City’s Green Painting” (2009-2010) (Figure 6c).
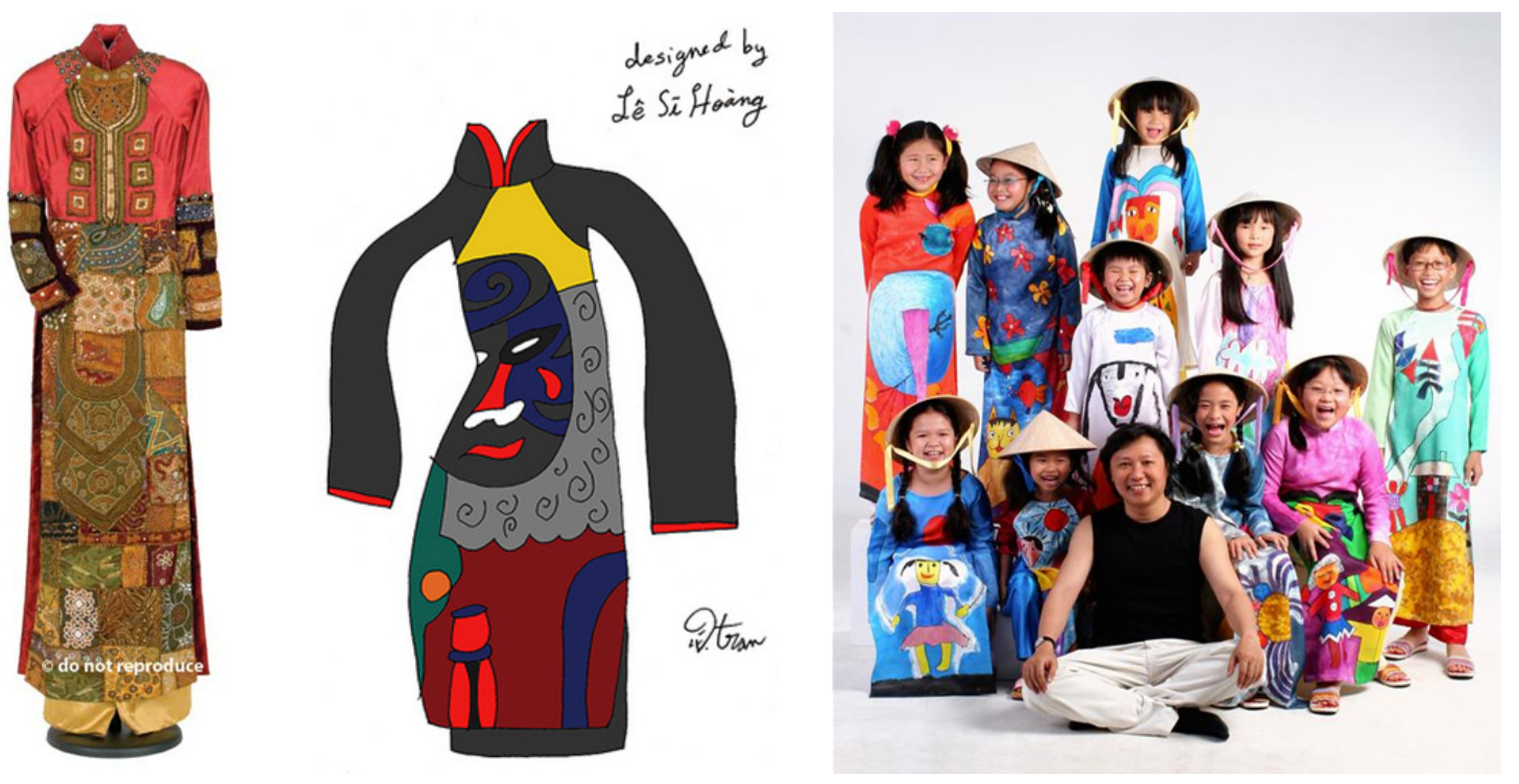

Figure $6(\mathrm{a}, \mathrm{b}, \mathrm{c})$

Figure 6a: Ao dai designed by Sy Hoang, Ao dai exhibition, San Jose - America in 2006.(Photo: Vietarts- San Jose)

Figure 6b: Ao dai illustration by Sy Hoang

Figure 6c: Sy Hoang with kids wearing his designs (Photo: vietpress)

Comment: Designer Sy Hoang has opened a new trend for renovating Ao dai of the Vietnamese women that highly contains painting and ornamental characters. In addition to that, he has spared no effort in building an "Ao dai culture" environment to maintain and transfer the beauty of the Vietnamese costumes to future generations of Vietnam.

\section{Conclusion}

To the end of the $19^{\text {th }}$ and the beginning of the $20^{\text {th }}$ centuries, Ao dai of the Vietnamese women has been much improved (both style and variety). As resulted from the compulsory impacts of the Western culture (started with the French colonialism), there came the first renovation movement during the 1930s often called "Ao dai Le Mur" (Ao dai Cat Tuong or Ao dai Le Pho). With that renovation, the aesthetic conception about the traditional beauty of the Vietnamese women first time met that of the Western women and both had been harmonized in 
modern Ao dai by using expression language for new fashion styles. That resulted in a new trend for designing Ao dai: fashionable but still containing specific characters of the Vietnamese women.

In the 1960s, under the stormy attack of the 'slightly characterized' pragmatic culture of the American, Ao dai once again acquired positive elements of that culture such as 'the joy to live' (Ao dai hippy), 'pragmatism' (Ao dai mini), the 'reasonableness' (Ao dai Raglan), the 'suggestive' (Ao dai Tran Le Xuan). During the second renovation movement, Ao dai of the Vietnamese women one more time continued to accept new aesthetic elements which were suitable to the aesthetic conception of the Vietnamese that was proved by the perfection of the Ao dai models in the 1970s.

The final renovation movement took place in the $1990 \mathrm{~s}$ of the $20^{\text {th }}$ century. The renovation this time typified an international exchange and the conservation of national characters in the field of Vietnamese culture in costumes. Minh Hanh and Ngan An's collections of Ao dai which were inspired by the beauty of costumes of different ethnic peoples in Vietnam and Si Hoang's from artistic painting and cultures of ethnic minorities in Vietnam, all have resulted in plentiful possibility to express Ao dai on the way to integrate into the region and the world.

From studying these three renovation movements and the typical designers in the $20^{\text {th }}$ century, it is found that on the foundation of plentiful and diversified cultures of Vietnam, by the unceasing efforts of the Vietnamese talented designers, how has Ao dai of the Vietnamese women accepted and assimilated the superior features of various cultures. As resulted of such efforts, there is one lap of Ao dai, very delicate but its beauty does help stirring the hearts of numerous persons when they contemplate it.

In future, there will certainly be more renovation movements. But what have been brought about by the renovation movements and the typical designers during the $20^{\text {th }}$ century are an invaluable contribution to the Ao dai of the Vietnamese women, and the harmonization of the aesthetic conception of the Vietnamese useful experience for the Vietnamese designers afterwards.

\section{References}

AodaiNgan, A. (2009). Brief introduction of designer Ngan An. Retrieved from http://aodainganan.com.vn/modules.php?name $=$ News\&op=viewst\&sid $=10$

BBC Vietnamese. (2011). Ba Tran Le Xuan qua doi. Retrieved from http://www.bbc.co.uk/vietnamese/vietnam/2011/04/110425_tranlexuan_dies.shtml

CAND. (2009). How's the First Lady Tran Le Xuan?. Retrieved from http://www.xaluan.com/modules.php?name=News\&file=article\&sid=141694

Hoai, N. (2006). A Female knight of Fashion. Retrieved from http:/tuoitre.vn/Tuoi-tre-cuoi-tuan/Tuoi-tre-cuoi-tuan/146400/\%E2\%80\%9Cnu-hiep-si\%E2\%80\%9D-thoi-t rang.html

Kim, D. (1996). Fashion 1996: Vietnam and the International. Tuan bao Quoc te. so tet, Ha Noi.

Ngo, D. T. (1994). Traditional costumes of Vietnamese people. Nha xuat ban Van hoa dan toc, trang 34, 39, Ha Noi.

Nguyen, C. T. (1934). Costume of women. Phong Hoatuan bao. so 86 - nam thu ba, trang4, Ha Noi.

Nguyen, C. T. (1934). The style of Aodai. Phong Hoatuan bao. so 90 - nam thu ba, trang4, Ha Noi.

Nguyen, L. T. B. (2005). Modern Vietnam fine arts. Vien My thuat - Truong dai hoc My thuat Ha Noi, trang 19, Ha Noi.

Nhieu, T. G. (2005). Ho Chi Minh city - 60 years of adopting the tradition of the August Revolution (1945-2005). Nha xuat ban Tong hop TP. HCM, Thanh pho Ho Chi Minh.

Phe, T. V. (2006). Lemur Aodai: “original” of current Aodai. Retrieved from http://www.hocxa.com/GiaiTri/GT_B/_B1_LuatHoiNga.php

Si, H. (2010). Art activity process: Artist - Designer Si Hoang. Retrieved from http://www.sihoang-art.com/aboutus/about.php

Toan, N. (2006). Designer Minh Hanh: Women are fragile and fool. Bao Cong AnNhan Dan. Retrieved from http://antgct.cand.com.vn/News/PrintView.aspx?ID=50772

\section{Notes}

Note 1. The origin of modern Ao dai, according to Tan a Newspaper, was created by a Vietnamese in 1921, which affected by the fashion style of a famous French designer Doenillet. Until 1929, this Ao dai model was 
brought to Hanoi by designer Chu Huong Mau and launched by artist Cat Tuong as "Ao dai Lemur". During 1933-1934, many Hanoi women started wearing it and spread all over the country (P.Thu. Vietnamese Women with A Sense of The Beauty And History of The National Dress. Records of Scientific Conference of the Women of Hanoi National University, 1997).

Note 2. The fashion "Hippy" from America came to Vietnam in early 70s; hippy culture (or hippie) includes liberal dress, against the routines. 